\title{
Non-association between low vitamin d levels and aeroallergen-positivity evaluated using multiple allergen simultaneous test in Korean adults
}

\author{
Jee Hye Wee', Sung Woo Cho ${ }^{2}$, Jeong-Whun $\mathrm{Kim}^{2}$ and Chae-Seo Rhee $3,4,5^{*}$ (1)
}

\begin{abstract}
Background: Studies on the association between vitamin D levels and allergen sensitization have reported conflicting results. We aimed to evaluate the association between low vitamin D levels and sensitization to 59 aeroallergens in Korean adults.
\end{abstract}

Methods: We retrospectively reviewed serum 25-hydroxyvitamin D (25[OH]D) measurements of participants $(n=57,467)$ in a healthcare center between May 2003 and June 2020. Serum 25(OH)D levels were categorized as follows: severe deficiency $(<10 \mathrm{ng} / \mathrm{mL}$ ), deficiency $(10$ to $<20 \mathrm{ng} / \mathrm{mL})$, insufficiency (20 to $<30 \mathrm{ng} / \mathrm{mL}$ ), and sufficiency $(\geq 30 \mathrm{ng} / \mathrm{mL}$ ). Among all subjects, 1277 simultaneously underwent the multiple allergen simultaneous test. Multiple linear and logistic regression analyses were used to estimate coefficients and odds ratios (ORs) with 95\% confidence interval (Cl) for the association between serum vitamin D deficiency and aeroallergen sensitization after adjustment for potential confounders. Subgroup analyses were conducted for the types of aeroallergen (house dust mites, pollens, animal dander, foods, cockroach, and fungus).

Results: Vitamin D deficiency, defined as serum $25(\mathrm{OH}) \mathrm{D}$ level $<20 \mathrm{ng} / \mathrm{mL}$, was noted in $56.4 \%$ of participants, There were significant differences in serum 25(OH)D levels according to sex, age, season, and bone mineral density (all $\mathrm{P}<0.001$ ). In multiple linear regression analyses, serum 25(OH)D levels were significantly lower in young subjects (adjusted coefficient [95\% Cl], $0.188[0.101,0.275])$ and during winter $(-4.114[-6.528,-1.699])$. However, no significant association was observed between serum 25(OH)D levels and allergen sensitization (adjusted coefficients $[95 \% \mathrm{Cl}],-0.211[-1.989,1.567], \mathrm{P}=0.816)$. In multivariate logistic regression analyses, male sex, young age, and winter season were significant risk factors for vitamin D deficiency. However, allergen sensitization showed no significant association with 25(OD)D levels after adjusting for confounders (adjusted OR [95\% Cl], 1.037 [0.642, 1.674] in insufficiency; $0.910[0.573,1.445]$ in deficiency; $0.869[0.298,2.539]$ in severe deficiency groups, $P$ for trend $=0.334$ ). There were consistent findings across subgroups regarding type of aeroallergen sensitized.

\footnotetext{
*Correspondence: csrhee@snu.ac.kr

${ }^{5}$ Department of Otorhinolaryngology-Head and Neck Surgery,

Seoul National University Hospital, Seoul National University College

of Medicine, 101 Daehagro, Jongro-gu, Seoul 03080, Korea

Full list of author information is available at the end of the article
}

\section{$\triangle B M C$} adaptation, distribution and reproduction in any medium or format, as long as you give appropriate credit to the original author(s) and the source, provide a link to the Creative Commons licence, and indicate if changes were made. The images or other third party material in this article are included in the article's Creative Commons licence, unless indicated otherwise in a credit line to the material. If material is not included in the article's Creative Commons licence and your intended use is not permitted by statutory regulation or exceeds the permitted use, you will need to obtain permission directly from the copyright holder. To view a copy of this licence, visit http://creativeco mmons.org/licenses/by/4.0/. The Creative Commons Public Domain Dedication waiver (http://creativecommons.org/publicdomain/ zero/1.0/) applies to the data made available in this article, unless otherwise stated in a credit line to the data. 
Conclusion: Vitamin D deficiency was prevalent but was not significantly associated with aeroallergen sensitization in Korean adults. To the best of our knowledge, this is the first large-scale study to evaluate the association between vitamin D deficiency and sensitization to 59 different aeroallergens.

Keywords: Vitamin D, Avitaminosis, Allergy and immunology, Population surveillance, Health care surveys

\section{Background}

Vitamin D has a unique feature that is synthesized by the skin in response to ultraviolet-B exposure, and its dietary sources are very limited [1]. Changes in indoor lifestyles and air pollution have resulted in an increased number of vitamin D deficiency cases, which has become a global public health problem. Approximately 1 billion people worldwide have vitamin D deficiency (defined as $<20 \mathrm{ng} /$ $\mathrm{mL}$ ), while $50 \%$ of the population has vitamin D insufficiency (defined as $21-29 \mathrm{ng} / \mathrm{mL}$ ) [2]. According to the data from the Korean National Health and Nutrition Examination Survey (KNHANES) 2008-2014, the prevalence of vitamin D deficiency (defined as $<20 \mathrm{ng} /$ $\mathrm{mL}$ ) was $51.8 \%$ and $68.2 \%$ in males and females in 2008 , but increased to $75.2 \%$ and $82.5 \%$ in 2014 , respectively [3].

Vitamin D status is generally determined based on serum 25-hydroxyvitamin D $(25[\mathrm{OH}] \mathrm{D})$ levels [4]. Although there has been extensive debate on the definition of vitamin D deficiency, vitamin D deficiency is defined as a serum $25(\mathrm{OH}) \mathrm{D}$ level of $<50 \mathrm{nmol} / \mathrm{L}$ or $20 \mathrm{ng} /$ $\mathrm{mL}$, while insufficiency is defined as a serum $25(\mathrm{OH})$ $\mathrm{D}$ level of $51-74 \mathrm{nmol} / \mathrm{L}$ (or $21-29 \mathrm{ng} / \mathrm{mL}$ ); sufficiency is defined as a serum $25(\mathrm{OH}) \mathrm{D}$ level of $>75 \mathrm{nmol} / \mathrm{L}$ (or $30 \mathrm{ng} / \mathrm{mL}$ ), generally $[1,5]$. Several studies have reported that vitamin D deficiency is correlated with an increased risk of non-bone-related disorders, such as hypertension, diabetes mellitus, rheumatoid arthritis, and infectious diseases [5-7]. Furthermore, given that vitamin D has gained increasing interest as an immune modulator, it is thought that vitamin $\mathrm{D}$ deficiency may be related to allergic diseases [8].

Many observational studies have reported on the relationship between serum 25(OH)D level and allergic diseases, but there are still conflicting results. A study by the KNHANES 2009 reported that subjects with low levels of serum $25(\mathrm{OH}) \mathrm{D}$ had a significantly higher risk of allergic rhinitis compared to those with serum $25(\mathrm{OH})$ D levels of at least $25 \mathrm{ng} / \mathrm{mL}$ (serum 25[OH]D lower than $15 \mathrm{ng} / \mathrm{mL}$ : hazard ratio, 95\% confidence interval [CI], 1.559 [1.099, 2.210]; serum 25[OH]D of at least 15 to lower than $25 \mathrm{ng} / \mathrm{mL}: 1.430$ [1.020, 2.006]) [9]. In contrast, a study conducted in the United States based on the third National Health and Nutrition Examination Survey reported that the prevalence of allergic rhinitis increased with increasing levels of $25(\mathrm{OH}) \mathrm{D}$ (odds ratio
[OR] [95\% CI], $1.25[1.03,1.53])[10]$. On the other hand, a meta-analysis showed that the pooled ORs for the incidence of allergic rhinitis according to vitamin D levels were not statistically significant for either children (OR [95\% CI], $0.91[0.41,2.03])$ or adults $(1.06[0.63,1.77])$ [11].

Furthermore, only a few studies have focused on the association between vitamin $\mathrm{D}$ levels and allergen sensitization [12-14]. They tested a small number of allergens: 1 allergen in a study conducted by Keet et al. [12], 3 allergens in a study published by Cheng et al. [13], and 17 allergens in a study conducted by Sharief et al. [14]. Moreover, the association of vitamin D levels and allergen sensitization remains controversial. Keet et al. [12] and Cheng et al. [13] reported that there was no association between vitamin $\mathrm{D}$ levels and allergen sensitization, whereas Sharief et al. [14] showed that there was some protective association between vitamin D deficiency and allergen sensitization. This study aimed to analyze serum vitamin D levels and to evaluate whether vitamin $\mathrm{D}$ deficiency is associated with sensitization to 59 aeroallergens after adjusting for potential confounders in Korean adults.

\section{Methods \\ Study population}

We used a clinical data warehouse (CDW) system [15] that was developed to provide big data analytics tools based on in-memory database technology in our hospital. This study was approved by the Institutional Review Board of Seoul National University Bundang Hospital (No. B-2008-630-005). Considering the retrospective study design, the requirement for informed consent was waived. We retrospectively collected data of the serum $25(\mathrm{OH}) \mathrm{D}$ measurements of participants $(\mathrm{n}=57,467)$ aged 20 years or older in Seoul National University Bundang Hospital Health Care Center between May 2003 and June 2020.

\section{Assessment of outcomes and confounders}

The enrolled subjects were categorized into five groups according to age in years $(20-29,30-39,40-49,50-59$, and $\geq 60$ years). The seasons during which blood samples were collected were divided into spring (March to May), summer (June to August), fall (September to November), and winter (December to February). Serum 25(OH) 
D levels were measured and expressed in $\mathrm{ng} / \mathrm{mL}$ using analysis on liquid chromatography/mass spectrometry. Serum 25(OH)D levels were categorized as follows: severe deficiency $(<10 \mathrm{ng} / \mathrm{mL})$, deficiency $(10$ to $<20 \mathrm{ng} /$ $\mathrm{mL}$ ), insufficiency (20 to $<30 \mathrm{ng} / \mathrm{mL}$ ), and sufficiency $(\geq 30 \mathrm{ng} / \mathrm{mL})[1,5]$. Histories of diabetes, hypertension, and hyperlipidemia were obtained. Bone mineral density was measured using dual-energy X-ray absorptiometry (DEXA). According to the World Health Organization study group, $\mathrm{T}$-scores at or above -1.0 are considered normal, those between -1.0 and -2.5 are considered as osteopenia, and those at or below -2.5 are considered as osteoporosis [16].

Among the enrolled study subjects, 1277 participants, who self-selected to have allergen sensitization testing done, simultaneously underwent the multiple allergen simultaneous test (MAST). MAST results were obtained for serum-specific IgE for 59 common aeroallergens (Additional file 1: Table S1). MAST-positive was defined as class $2(\geq 0.7 \mathrm{IU} / \mathrm{mL})$ or more to an at least one allergen $[17,18]$. The 59 aeroallergens were divided into seven allergen groups: house dust mites, pollens, animal dander, foods, cockroach, fungus, and others.

\section{Statistical analysis}

Data of the prevalence of vitamin D deficiency were presented as percentage \pm standard deviation (SD) for each group. Student's $t$ test or ANOVA was used to compare the mean serum 25(OH)D levels across the demographic categories. The chi-square test was used to determine whether there were significant differences between the allergen-positive and allergen-negative groups among vitamin D level categories. Multiple linear regression analysis was performed to identify potential confounding variables of serum $25(\mathrm{OH}) \mathrm{D}$ levels. The following independent variables were included in the model: age (as a continuous variable), sex, season, bone mineral density, medical diseases, and allergen sensitization (as categorical variables).

Multivariate logistic regression models were also created to calculate the adjusted ORs and their $95 \%$ CIs of the risk factors on comparing 25(OH)D levels of $<10 \mathrm{ng} /$ $\mathrm{mL}, 10$ to $<20 \mathrm{ng} / \mathrm{mL}$, and 20 to $<30 \mathrm{ng} / \mathrm{mL}$ with $25(\mathrm{OH})$ D levels of $\geq 30 \mathrm{ng} / \mathrm{mL}$. A P-value of less than 0.05 was considered to indicate statistical significance. Statistical analyses were conducted using SPSS complex version 22.0 (IBM, Armonk, NY, USA).

\section{Results}

Serum 25(OH)D levels according to subject characteristics are presented in Table 1 . The mean serum $25(\mathrm{OH}) \mathrm{D}$ level was lower in men $(20.0 \pm 8.3 \mathrm{ng} / \mathrm{mL})$ than in women $(20.4 \pm 10.5 \mathrm{ng} / \mathrm{mL})(\mathrm{P}<0.001)$. Participants
Table 1 The serum levels of 25(OH)D by the characteristics of participants

\begin{tabular}{|c|c|c|c|}
\hline & No. & $\begin{array}{l}\text { Serum 25(OH)D level } \\
\text { (mean } \pm \text { SD, ng } / \mathrm{mL} \text { ) }\end{array}$ & P-value \\
\hline Overall & 57,467 & $20.2 \pm 9.3$ & \\
\hline \multicolumn{4}{|l|}{ Sex } \\
\hline Male & 31,520 & $20.0 \pm 8.3$ & $<0.001^{*}$ \\
\hline Female & 25,947 & $20.4 \pm 10.5$ & \\
\hline \multicolumn{4}{|l|}{ Age group } \\
\hline $20-29$ & 2674 & $16.0 \pm 7.3$ & $<0.001^{\dagger}$ \\
\hline $30-39$ & 6796 & $17.2 \pm 7.7$ & \\
\hline $40-49$ & 14,543 & $18.3 \pm 8.0$ & \\
\hline $50-59$ & 19,569 & $20.8 \pm 9.2$ & \\
\hline$\geq 60$ & 13,885 & $23.6 \pm 10.5$ & \\
\hline \multicolumn{4}{|l|}{ Season } \\
\hline Spring & 14,565 & $19.6 \pm 9.9$ & $<0.001^{\dagger}$ \\
\hline Summer & 14,671 & $21.2 \pm 8.5$ & \\
\hline Fall & 13,555 & $21.1 \pm 8.9$ & \\
\hline Winter & 14,676 & $18.9 \pm 9.7$ & \\
\hline DEXA & & & $<0.001^{+}$ \\
\hline Normal & 15,437 & $19.5 \pm 8.9$ & \\
\hline Osteopenia & 8048 & $21.2 \pm 10.1$ & \\
\hline Osteoporosis & 1762 & $23.0 \pm 10.6$ & \\
\hline Missing & 32,220 & & \\
\hline MAST & & & 0.265 \\
\hline Positive & 617 & $21.1 \pm 9.2$ & \\
\hline Negative & 660 & $21.7 \pm 8.2$ & \\
\hline Missing & 56,190 & & \\
\hline
\end{tabular}

SD standard deviation, DEXA Dual energy X-ray absorptiometry, MAST multiple allergen simultaneous test

* Student's $t$ test, ${ }^{\dagger}$ ANOVA test, with $P<0.05$ considered significant

aged $<30$ years had the lowest serum $25(\mathrm{OH}) \mathrm{D}$ levels $(16.0 \pm 7.3 \mathrm{ng} / \mathrm{mL})$, whereas those aged $\geq 60$ years had the highest serum $25(\mathrm{OH}) \mathrm{D}$ levels $(23.6 \pm 10.5 \mathrm{ng} / \mathrm{mL})$; this difference was statistically significant $(\mathrm{P}<0.001)$. Serum $25(\mathrm{OH}) \mathrm{D}$ levels were observed to be lower in the winter $(18.9 \pm 9.7 \mathrm{ng} / \mathrm{mL})$ than in the summer $(21.2 \pm 8.5 \mathrm{ng} / \mathrm{mL})(\mathrm{P}<0.001)$. The mean serum $25(\mathrm{OH})$ D level was significantly lower in participants with a normal T-score in DEXA $(19.5 \pm 8.9 \mathrm{ng} / \mathrm{mL})$ than in those with a decreased T-score $(21.2 \pm 10.1 \mathrm{ng} / \mathrm{mL}$ in osteopenia; $23.0 \pm 10.6 \mathrm{ng} / \mathrm{mL}$ in osteoporosis; $\mathrm{P}<0.001$ ). However, mean serum 25(OH)D levels did not show significant differences between the MAST-positive $(\mathrm{n}=617,21.1 \pm 9.2 \mathrm{ng} / \mathrm{mL})$ and MAST-negative $(\mathrm{n}=660$, $21.7 \pm 9.2 \mathrm{ng} / \mathrm{mL})$ groups $(\mathrm{P}=0.265)$. Serum $25(\mathrm{OH}) \mathrm{D}$ levels by the characteristics of 1277 participants who had undergone MAST showed consistent results (Additional file 1: Table S2).

The mean $25(\mathrm{OH}) \mathrm{D}$ level was $20.2 \pm 9.3 \mathrm{ng} / \mathrm{mL}$ (range: $2.0-141.8 \mathrm{ng} / \mathrm{mL}$ ), and $9.7 \%, 56.4 \%$, and $86.1 \%$ of the 


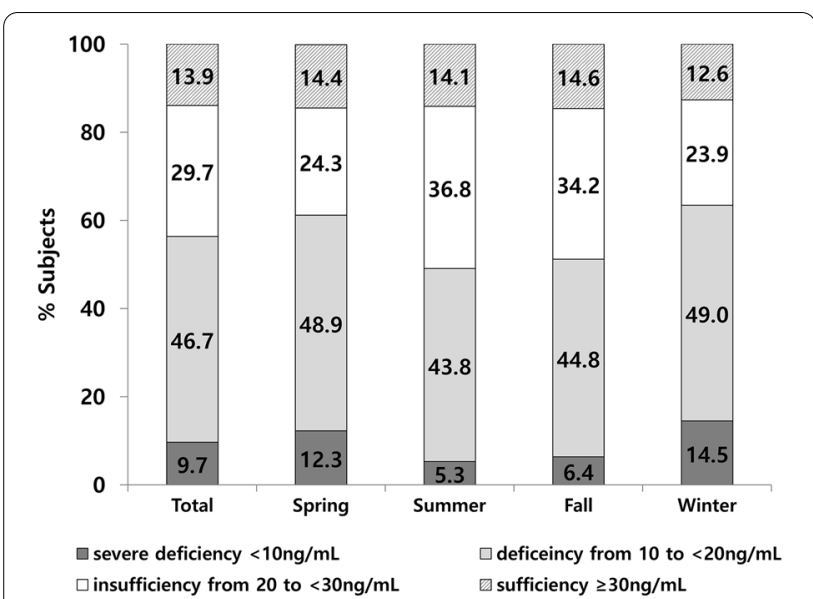

Fig. 1 The percentage of participants with serum $25(\mathrm{OH}) \mathrm{D}$ levels of $<10 \mathrm{ng} / \mathrm{mL}$, 10 to $<20 \mathrm{ng} / \mathrm{mL}$, and 20 to $<30 \mathrm{ng} / \mathrm{mL}$ and $\geq 30 \mathrm{ng} /$ $\mathrm{mL}$ according to the season

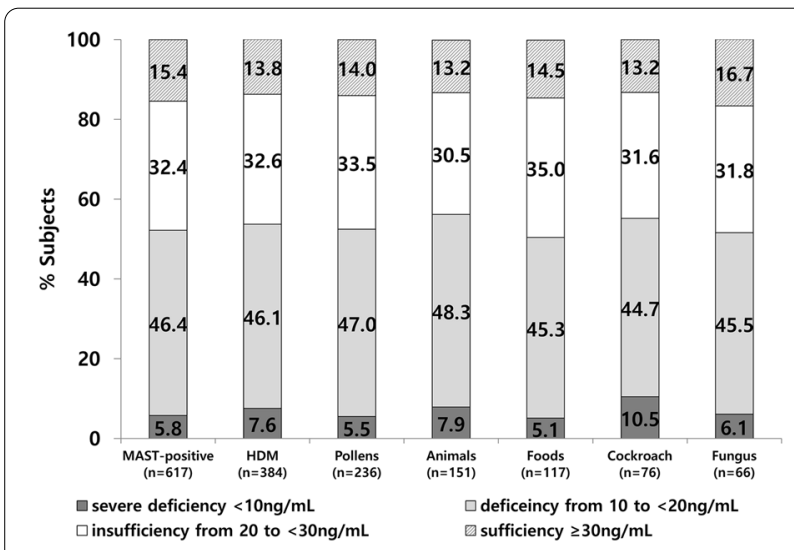

Fig. 2 The percentage of MAST-positive participants with serum $25(\mathrm{OH})$ D levels of $<10 \mathrm{ng} / \mathrm{mL}, 10$ to $<20 \mathrm{ng} / \mathrm{mL}$, and 20 to $<30 \mathrm{ng} / \mathrm{mL}$ and $\geq 30 \mathrm{ng} / \mathrm{mL}$ according to the types of aeroallergen sensitized

subjects had 25(OH)D levels of $<10 \mathrm{ng} / \mathrm{mL},<20 \mathrm{ng} /$ $\mathrm{mL}$, and $<30 \mathrm{ng} / \mathrm{mL}$, respectively (Fig. 1). Figure 1 shows the prevalence of vitamin D deficiency according to the seasons. Even in the summer, almost half of the subjects (49.1\%) showed vitamin D deficiency $(<20 \mathrm{ng} /$ $\mathrm{mL}$ ). Figure 2 shows the proportion of vitamin D level categories in MAST-positive participants according to the types of aeroallergen sensitized. More than half of the subjects had vitamin D deficiency $(<20 \mathrm{ng} / \mathrm{mL})$ in all subgroups. There was no significant difference between the MAST-positive and MAST-negative groups in vitamin $\mathrm{D}$ level categories $(\mathrm{P}=0.441)$ and there was also no significant difference when analyzed by each allergen type (all $\mathrm{P}>0.05$, Table 2 ). In addition, among the 617 subjects (MAST-positive), 340 patients (55.1\%) had a single category of aeroallergen sensitization and 277 (44.9\%) patients had multiple categories of sensitization, showing no significant difference between the two groups in vitamin $\mathrm{D}$ level categories $(\mathrm{P}=0.505)$.

On multiple linear regression analysis, serum $25(\mathrm{OH})$ D levels were significantly lower in young subjects (adjusted coefficients [95\% CI], 0.188 [0.101, 0.275], $\mathrm{P}<0.001)$ and during winter $(-4.114[-6.528,-1.699]$, $\mathrm{P}=0.001$ ) (Table 3). However, no significant association was observed between serum 25(OH)D levels and MAST-positivity after adjusting for confounders such as sex, age, season, and medical diseases including osteopenia and osteoporosis (adjusted coefficient [95\% $\mathrm{CI}],-0.211[-1.989,1.567], \mathrm{P}=0.816)$. When stratified by types of aeroallergen sensitized, there was also no significant association (all $\mathrm{P}>0.05$, Table 4).

Tables 5 shows adjusted ORs for the associations between risk factors and different serum 25(OH)D levels. Multiple logistic regression analyses after adjusting for variables showed the following significant risk factors for vitamin D deficiency: male sex (P for trend $<0.001$ ), young age ( $\mathrm{P}$ for trend $<0.001)$, and winter season ( $\mathrm{P}$ for trend $=0.002)$. However, no significant association was observed between MAST-positivity and vitamin D deficiency (adjusted OR [95\% CI], 1.037 [0.642, 1.674], $\mathrm{P}=0.882$ in insufficiency; $0.910[0.573,1.445], \mathrm{P}=0.689$ in deficiency; 0.869 [0.298, 2.539], $\mathrm{P}=0.148$ in severe deficiency groups; $\mathrm{P}$ for trend $=0.334$ ). In subgroup analysis according to the types of aeroallergen sensitized, there was no significant association between allergen sensitization and vitamin $\mathrm{D}$ deficiency (all $\mathrm{P}>0.05$, Table 6).

\section{Discussion}

To analyze the association between allergen sensitization and low vitamin D levels, we determined the serumspecific IgE levels for 59 common airborne indoor and outdoor allergens. We could not observe any significant association between serum vitamin D levels and allergen sensitization. There were consistent findings across subgroups regarding the types of aeroallergen sensitized. To the best of our knowledge, this is the first large-scale study to evaluate the association between vitamin D deficiency and sensitization to 59 different aeroallergens.

Only few studies have been conducted on the association between vitamin $\mathrm{D}$ levels and allergen sensitization, and the relationship is still unclear. A cohort study that included 260 subjects in the U.S. reported that serum vitamin D levels were not associated with incident mouse sensitization (OR $[95 \% \mathrm{CI}], 3.2[0.7,14.1], \mathrm{P}=0.13)$ [12]. A crosssectional population-based study that used data from the KNHANES 2008-2010 showed no association 
Table 2 Percentage of serum 25(OH)D levels of $<10 \mathrm{ng} / \mathrm{mL}$, 10 to $<20 \mathrm{ng} / \mathrm{mL}$, 20 to $<30 \mathrm{ng} / \mathrm{mL}$, and $\geq 30 \mathrm{ng} / \mathrm{mL}$ according to the allergen sensitization

\begin{tabular}{|c|c|c|c|c|c|}
\hline \multirow[t]{2}{*}{ Variables } & \multicolumn{4}{|l|}{ Participants (n, \%) } & \multirow[t]{2}{*}{ P-value* } \\
\hline & Serum $25(\mathrm{OH}) \mathrm{D} \geq 30$ & $\begin{array}{l}20 \leq \text { Serum } 25(\mathrm{OH}) \\
\mathrm{D}<30\end{array}$ & $\begin{array}{l}10 \leq \text { Serum } 25(\mathrm{OH}) \\
\mathrm{D}<20\end{array}$ & $\begin{array}{l}\text { Serum } 25(\mathrm{OH}) \\
D<10\end{array}$ & \\
\hline MAST & & & & & 0.441 \\
\hline Positive $(n=617)$ & $95(15.4)$ & $200(32.4)$ & $286(46.4)$ & $36(5.8)$ & \\
\hline Negative $(n=660)$ & $118(17.9)$ & $220(33.3)$ & $279(42.3)$ & $43(6.5)$ & \\
\hline House dust mites & & & & & 0.185 \\
\hline Positive $(n=384)$ & $53(13.8)$ & $125(32.6)$ & $177(44.2)$ & $29(6.2)$ & \\
\hline Negative $(n=893)$ & $160(17.9)$ & $295(33.0)$ & $388(43.4)$ & $50(5.6)$ & \\
\hline Pollens & & & & & 0.569 \\
\hline Positive $(n=236)$ & $33(14.0)$ & 79 (33.5) & $111(47.0)$ & $13(5.5)$ & \\
\hline Negative $(n=1041)$ & $180(17.3)$ & $341(32.8)$ & $454(43.6)$ & $66(6.3)$ & \\
\hline Animal dander & & & & & 0.388 \\
\hline Positive $(n=151)$ & $20(13.2)$ & $46(30.5)$ & $73(48.3)$ & $12(7.9)$ & \\
\hline Negative $(n=1126)$ & $193(17.1)$ & $374(33.2)$ & $492(43.7)$ & $67(6.0)$ & \\
\hline Foods & & & & & 0.849 \\
\hline Positive $(n=117)$ & $17(14.5)$ & $41(35.0)$ & $53(45.3)$ & $6(5.1)$ & \\
\hline Negative $(n=1160)$ & $196(16.9)$ & $379(32.7)$ & $512(44.1)$ & $73(6.3)$ & \\
\hline Cockroach & & & & & 0.375 \\
\hline Positive $(n=76)$ & $10(13.2)$ & $24(31.6)$ & $34(44.7)$ & $8(10.5)$ & \\
\hline Negative $(n=1201)$ & $203(16.9)$ & $396(33.0)$ & $531(44.2)$ & $71(5.9)$ & \\
\hline Fungus & & & & & 0.997 \\
\hline Positive $(n=66)$ & $11(16.7)$ & $21(31.8)$ & $30(45.5)$ & $4(6.1)$ & \\
\hline Negative $(n=1211)$ & $202(16.7)$ & 399 (32.9) & $535(44.2)$ & $75(6.2)$ & \\
\hline
\end{tabular}

MAST: multiple allergen simultaneous test

${ }^{*}$ Chi-square test, with $P<0.05$ considered significant

Table 3 Results of a multiple linear regression analysis on variables of vitamin D levels

\begin{tabular}{|c|c|c|c|}
\hline Variables & Adjusted coefficients (SD) & $95 \% \mathrm{Cl}$ & $P$-value \\
\hline Sex (male) & $-0.637(0.915)$ & -2.437 to 1.162 & 0.486 \\
\hline Age & $0.188(0.915)$ & 0.101 to 0.275 & $<0.001^{*}$ \\
\hline \multicolumn{4}{|l|}{ Season } \\
\hline Spring & $-2.113(1.248)$ & -4.567 to -0.341 & 0.091 \\
\hline Summer & Reference & & \\
\hline Fall & $0.098(1.274)$ & -2.409 to 2.605 & 0.939 \\
\hline Winter & $-4.114(1.227)$ & -6.528 to -1.699 & $0.001^{*}$ \\
\hline \multicolumn{4}{|l|}{ DEXA } \\
\hline Normal & Reference & & \\
\hline Osteopenia & $0.364(0.963)$ & -1.531 to 2.259 & 0.706 \\
\hline Osteoporosis & $1.043(1.871)$ & -2.639 to 4.725 & 0.578 \\
\hline Diabetes mellitus & $-0.764(1.160)$ & -3.046 to 1.519 & 0.511 \\
\hline Hypertension & $-0.271(0.543)$ & -3.046 to 1.519 & 0.618 \\
\hline Hypercholesterolemia & $-0.164(0.395)$ & -0.613 to 0.941 & 0.678 \\
\hline MAST (Positive) & $-0.211(0.904)$ & -1.989 to 1.567 & 0.816 \\
\hline
\end{tabular}

$S D$ standard deviation, $C l$ confidence interval, DEXA dual energy $\mathrm{x}$-ray absorptiometry, MAST multiple allergen simultaneous test

${ }^{*}$ Multiple linear regression analysis, with $P<0.05$ considered significant 
Table 4 Associations between allergen sensitization and serum 25(OH)D levels according to types of aeroallergen

\begin{tabular}{rccc}
\hline \multicolumn{1}{l|}{ Types of aeroallergen } & Adjusted coefficients (SD) & 95\% Cl & P-value* \\
\hline House dust mites $(n=384)$ & $0.271(1.069)$ & -1.831 to 2.374 & 0.800 \\
Pollens $(n=236)$ & $-0.175(0.569)$ & -1.294 to 0.943 & 0.758 \\
Animal dander $(n=151)$ & $0.308(0.528)$ & -0.731 to 1.346 & 0.560 \\
Foods $(n=117)$ & $0.173(0.329)$ & -0.474 to 0.821 & 0.599 \\
Cockroach $(n=76)$ & $0.054(0.391)$ & -0.715 to 0.822 & 0.891 \\
Fungus $(n=66)$ & $0.356(0.470)$ & -0.568 to 1.280 & 0.449 \\
\hline
\end{tabular}

SD standard deviation, $\mathrm{Cl}$ confidence interval

*Multiple linear regression analysis, adjusted for age, sex, season, and medical diseases (osteopenia, osteoporosis, diabetes mellitus, hypertension, and hypercholesterolemia), with $P<0.05$ considered significant

Table 5 Adjusted odds ratios for the association between risk factors and serum $25(\mathrm{OH}) \mathrm{D}$ levels of $<10 \mathrm{ng} / \mathrm{mL}, 10$ to $<20 \mathrm{ng} / \mathrm{mL}$, and 20 to $<30 \mathrm{ng} / \mathrm{mL}$ compared with the reference group ( $\geq 30 \mathrm{ng} / \mathrm{mL}$ )

\begin{tabular}{|c|c|c|c|c|c|}
\hline \multirow[t]{2}{*}{ Variables } & \multicolumn{4}{|c|}{ Adjusted ORs (95\% confidence interval) } & \multirow[t]{2}{*}{$P$ for trend } \\
\hline & $\begin{array}{l}\text { Serum } \\
25(O H) \\
D \geq 30\end{array}$ & $20 \leq$ Serum $25(\mathrm{OH}) \mathrm{D}<30$ & $10 \leq$ Serum $25(\mathrm{OH}) \mathrm{D}<20$ & Serum $25(\mathrm{OH}) \mathrm{D}<10$ & \\
\hline Sex (male) & 1 & $2.212(1.351-3.622)^{*}$ & $1.937(1.204-3.117)^{*}$ & $0.470(0.170-1.300)$ & $<0.001$ \\
\hline Age group & & & & & $<0.001$ \\
\hline $20-29$ vs $\geq 60$ & 1 & N/A & $2.171(0.199-23.697)$ & N/A & \\
\hline $30-39 v s \geq 60$ & 1 & $3.656(1.070-12.491)^{*}$ & $4.686(1.422-15.441)^{*}$ & $11.736(2.124-64.850)^{*}$ & \\
\hline $40-49$ vs $\geq 60$ & 1 & $4.496(1.775-11.387)^{*}$ & $7.627(3.135-18.557)^{*}$ & $13.978(3.449-56.660)^{*}$ & \\
\hline $50-59$ vs $\geq 60$ & 1 & $3.187(1.844-5.509)^{*}$ & $4.376(2.577-7.431)^{*}$ & $5.868(1.970-17.477)^{*}$ & \\
\hline Season & & & & & 0.002 \\
\hline Spring vs Winter & 1 & $0.428(0.223-0.821)^{*}$ & $0.510(0.279-0.933)$ & $0.423(0.160-1.114)$ & \\
\hline Summer vs Winter & 1 & $0.922(0.470-1.809)$ & $0.621(0.321-1.202)$ & $0.149(0.037-0.599)^{*}$ & \\
\hline Fall vs Winter & 1 & $1.065(0.540-2.103)$ & $0.676(0.347-1.320)$ & $0.235(0.065-0.844)^{*}$ & \\
\hline DEXA & & & & & 0.274 \\
\hline Normal vs Osteoporosis & 1 & $1.037(0.460-2.337)$ & $1.770(0.766-4.093)$ & N/A & \\
\hline Osteopenia vs Osteoporosis & 1 & $0.795(0.341-1.853)$ & $1.150(0.481-2.751)$ & N/A & \\
\hline Diabetes mellitus & 1 & $0.782(0.420-1.458)$ & $1.371(0.770-2.442)$ & $0.804(0.211-3.066)$ & 0.172 \\
\hline Hypertension & 1 & $1.311(0.755-2.275)$ & $1.090(0.638-1.860)$ & $1.022(0.333-3.135)$ & 0.777 \\
\hline Hypercholesterolemia & 1 & $0.741(0.408-1.347)$ & $0.834(0.471-1.477)$ & $0.435(0.090-2.094)$ & 0.615 \\
\hline MAST (Positive) & 1 & $1.037(0.642-1.674)$ & $0.910(0.573-1.445)$ & $0.869(0.298-2.539)$ & 0.334 \\
\hline
\end{tabular}

DEXA dual energy X-ray absorptiometry, MAST multiple allergen simultaneous test

* Multivariate logistic regression analyses, with $P<0.05$ considered significant

between serum vitamin $\mathrm{D}$ levels and sensitization to three allergens sensitization (Dermatophagoides farinae: OR [95\% CI], 0.86 [0.61, 1.21]; cockroaches: 1.25 [0.75. 2.06]; and dogs: 1.58 [0.80, 3.11]) [13]. These findings are consistent with those observed in our study, although they tested a small number of allergens. In contrast, a large cross-sectional study in the U.S. found a significant association between serum vitamin $D$ levels and allergen sensitization in three out of 11 allergens in adults [14]. They showed that $25(\mathrm{OH}) \mathrm{D}$ levels of $15-29 \mathrm{ng} / \mathrm{mL}$ had protective associations with sensitization to $\operatorname{dog}(\mathrm{OR}[95 \% \mathrm{CI}], 0.71[0.53,0.96])$ and cockroach allergens (OR [95\% CI] $0.64[0.43,0.94])$, and levels of less than $15 \mathrm{ng} / \mathrm{mL}$ showed a protective association with ragweed allergy (OR [95\% CI], 0.60 $[0.40,0.89])[14]$. However, in all subgroups according to the types of aeroallergen sensitized, we found no correlation between vitamin D deficiency and allergen sensitization.

The results suggesting that there is no association between vitamin $D$ levels and allergen sensitization in adults can be explained by several factors. First, if the 
Table 6 Adjusted odds ratios for the association between aeroallergen sensitization and serum 25(OH)D levels of $<10 \mathrm{ng} / \mathrm{mL}$, 10 to $<20 \mathrm{ng} / \mathrm{mL}$, and 20 to $<30 \mathrm{ng} / \mathrm{mL}$ compared with the reference group ( $\geq 30 \mathrm{ng} / \mathrm{mL}$ ) according to the types of aeroallergen sensitization

\begin{tabular}{|c|c|c|c|c|c|}
\hline \multirow[t]{2}{*}{ Types of aeroallergen } & \multicolumn{4}{|c|}{ Adjusted ORs ( $95 \%$ confidence interval) } & \multirow[t]{2}{*}{$P$ for trend } \\
\hline & $\begin{array}{l}\text { Serum } \\
25(\mathrm{OH}) \\
D \geq 30\end{array}$ & $20 \leq$ Serum $25(\mathrm{OH}) \mathrm{D}<30$ & $10 \leq$ Serum $25(\mathrm{OH}) \mathrm{D}<20$ & Serum $25(\mathrm{OH}) \mathrm{D}<10$ & \\
\hline House dust mites $(n=384)$ & 1 & $0.973(0.566-1.671)$ & $0.977(0.577-1.652)$ & $0.728(0.273-1.942)$ & 0.930 \\
\hline Pollens $(n=236)$ & 1 & $0.871(0.479-1.583)$ & $0.978(0.553-1.731)$ & $0.663(0.204-2.154)$ & 0.864 \\
\hline Animal dander $(n=151)$ & 1 & $0.626(0.290-1.353)$ & $0.691(0.335-1.422)$ & $0.315(0.063-1.578)$ & 0.426 \\
\hline Foods $(n=117)$ & 1 & $0.791(0.381-1.641)$ & $0.622(0.305-1.268)$ & $0.193(0.023-1.605)$ & 0.244 \\
\hline Cockroach $(n=76)$ & 1 & $0.712(0.276-1.839)$ & $0.536(0.208-1.379)$ & $0.541(0.057-5.114)$ & 0.631 \\
\hline Fungus $(n=66)$ & 1 & $0.823(0.294-2.300)$ & $0.790(0.289-2.160)$ & $\mathrm{N} / \mathrm{A}$ & 0.272 \\
\hline
\end{tabular}

* Multivariate logistic regression analyses, adjusted with sex, age group, season, and medical diseases (osteopenia, osteoporosis, diabetes mellitus, hypertension, and hypercholesterolemia) with $P<0.05$ considered significant

allergies have begun in childhood, then the levels of serum $25(\mathrm{OH}) \mathrm{D}$ in adults may not reflect the $25(\mathrm{OH})$ $\mathrm{D}$ status at the time of allergen sensitization. A metaanalysis showed that the associations between vitamin $D$ deficiency and allergen sensitization were seen in children and adolescents but not in adults [19]. Second, it has been speculated that the role of vitamin $D$ in allergen sensitization depends on ethnicity. A previous study showed that specific genotypes modify the association between vitamin D deficiency and allergy risk in adults [20]. Third, expression of some immune system factors involved in allergen sensitization has been shown to be age-dependent. Vitamin D regulates the expression of pattern recognition receptors, such as CD14 [21]. CD14 polymorphism and serum CD14 levels are related to allergen sensitization and are agespecific, which are present during mid-childhood but not in early adulthood [22, 23]. However, further studies are needed to determine the precise role of vitamin D in the pathophysiology of allergen sensitization.

Previous studies have suggested a link between allergic disease/allergen sensitization and low vitamin D level, and recommendations for vitamin D supplementation have also been strengthened. However, the preventive or therapeutic effect of vitamin D supplementation on allergic disease remains controversial. In a birth cohort study from the United States, there was no association between maternal intake of vitamin $\mathrm{D}$ during pregnancy and allergen sensitization and allergic rhinitis at school age [24]. In cohort studies conducted in Finland and Germany, a significantly higher rate of allergen sensitization and allergic rhinitis at 31 years of age was observed in a group that had regularly consumed vitamin D supplements in infancy [25], and higher maternal $25(\mathrm{OH}) \mathrm{D}$ concentration was associated with an increased risk of food allergen sensitization at the age of 2 years [26]. In contrast, a randomized double-blind placebocontrolled study showed that vitamin D supplementation along with antihistamines resulted in relative symptom improvement in allergic rhinitis patients with vitamin D deficiency. Based on these findings, it is unclear whether vitamin D supplementation should be recommended. Moreover, in the present study, vitamin D deficiency was prevalent, even in the summer, but was not associated with an increased risk of aeroallergen sensitization.

Our study showed that serum vitamin D levels were significantly lower in males and young subjects than in females and older subjects among Korean adults. Globally, vitamin D deficiency is known to be more prevalent in older age groups and to have no significant sex-related differences [6, 27]. Although we cannot state the exact cause of these conflicting results, one possible cause is regional difference. A recent systematic review about vitamin D status in the population reported differences according to regions, with vitamin D levels being significantly higher in North America than in Europe or the Middle East/Africa region [6]. In the Asia/ Pacific region, 25(OH)D values were lower in children/ adolescents than in adults/elderly people; furthermore, females tended to have significantly low $25(\mathrm{OH}) \mathrm{D}$ values [6]. A recent study based on the KNHANES 2008-2014 showed a significantly increasing trend in vitamin D deficiency and showed that vitamin D deficiency was prevalent in young adults, in females, and in the winter [3].

The definition of vitamin D deficiency has been under extensive debate. Unlike the commonly used definition for vitamin D deficiency, serum 25(OH)D levels can be divided into adequate $(\geq 50 \mathrm{nmol} / \mathrm{L}$ or $20 \mathrm{ng} / \mathrm{mL})$, inadequate $(30$ to $<50 \mathrm{nmol} / \mathrm{L}$ or 12 to $<20 \mathrm{ng} / \mathrm{mL}$ ), and 
deficient $(<30 \mathrm{nmol} / \mathrm{L}$ or $12 \mathrm{ng} / \mathrm{mL})$ according to the Institute of Medicine guidelines [28]. Current evidencebased consensus guidelines have not been established, and this is of concern because individuals with serum $25(\mathrm{OH}) \mathrm{D}$ levels ranging from 20 to $<30 \mathrm{ng} / \mathrm{mL}$ may be classified to have insufficiency or adequate status. In the present study, vitamin D insufficiency (serum 25[OH]D level of $<30 \mathrm{ng} / \mathrm{mL}$ ) was found in most $(86.1 \%)$ Korean adults. A higher threshold level of serum 25(OH)D would be expected to artificially increase the incidence of vitamin D deficiency. Furthermore, this definition is based on Western populations, and racial/genetic differences could affect the adequate vitamin D level. As there will be differences in vitamin $\mathrm{D}$ levels by race/ ethnicity, we believe that this Asian study on vitamin D levels, conducted within a single ethnic group, is important, although we could not analyze the results according to race/ethnicity. Additional studies will be needed to evaluate the exact range of vitamin $D$ levels for maintaining bone health and avoiding non-bone-related disorders, including allergic disease, according to sex, age, season, and region in Korea.

The present study has some limitations. First, because it was a cross-sectional study, it was not possible to determine a clear causal relationship between risk factors and vitamin D deficiency and to evaluate the historical levels of vitamin D. Second, we could not perform assessments for allergic rhinitis and asthma. In addition, we did not obtain information about medications including vitamin $\mathrm{D}$ supplementation. The serum 25(OH)D levels of subjects with osteopenia or osteoporosis were higher than those of normal subjects, suggesting that participants may have been taking vitamin D supplementation. Lastly, the number of subjects who underwent allergic tests (MAST) was small, compared to the total number of participants included. The possibility of biased results cannot be overlooked, as the participants who visited a health screening center have decided whether to test for allergen sensitization. We used the conventional cutoff level of class 2 as the minimal positive result criteria, but the use of class 1 as a cutoff level could result in an additional 532 patients being included in the MAST-positive group (Additional file 1, Table S3). However, there was no significant difference in serum $25(\mathrm{OH}) \mathrm{D}$ levels between the three groups.

Despite these limitations, a potential strength of the present study was that it enrolled a large number of subjects using the CDW system and analyzed a wide array of aeroallergen (59) compared to previous studies. Further studies on a larger general population who had undergone allergic testing could show more clinically significant results.

\section{Conclusions}

Vitamin D deficiency was not associated with an increased risk of allergen sensitization among Korean adults. It is unclear whether vitamin D supplementation should be recommended for prevention of allergic disease. Furthermore, vitamin D deficiency was prevalent, even in the summer, and was more common in Korean males and young individuals. Additional studies are needed to elucidate the adequate vitamin $\mathrm{D}$ levels according to sex, age, and racial/genetic differences.

\section{Supplementary Information}

The online version contains supplementary material available at https://doi. org/10.1186/s13223-021-00525-6.

Additional file 1: Table S1. Fifty-nine aeroallergens tested by MAST Table S2. The serum levels of 25(OH)D by the characteristics of 1277 participants who had MAST done. Table S3 The serum levels of 25(OH)D according to the results of MAST.

\section{Abbreviations}

KNHANES: Korean National Health and Nutrition Examination Survey; $25[\mathrm{OH}]$ D: 25-Hydroxyvitamin D; Cl: Confidence interval; OR: Odds ratio; CDW: Clinical data warehouse; DEXA: Dual energy X-ray absorptiometry; MAST: Multiple allergen simultaneous test; SD: Standard deviation.

\section{Acknowledgements}

Not applicable.

\section{Authors' contributions}

JWK and CSR designed research; JHW and SWC recruited the data and performed the data analyses and statistical analyses. JHW wrote the first draft of the manuscript, which was critically revised by SWC, JWK, and CSR. JHW received the fund. All authors read and approved the final manuscript.

\section{Funding}

This research was funded by National Research Foundation (NRF) of Korea, Grant Number (NRF-2020-R1G1A1005390 by Jee Hye Wee). The funding organization did not contribute to the design or conduct of this study, preparation, review, approval, or decision to submit this manuscript for publication.

\section{Availability of data and materials}

The datasets used and/or analyzed during the current study are available from the corresponding author on reasonable request.

\section{Ethics approval and consent to participate}

The study was performed in accordance with ethical standard of the institutional research committee and with the 1964 Helsinki declaration and its later amendments or comparable ethical standards. The study was approved by the ethics committee of Seoul National University Bundang Hospital (No. B-2008-630-005). The requirement for written informed consent was waived by the Institutional Review Board due to retrospective chart review.

\section{Consent for publication}

Not applicable.

\section{Competing interests}

The authors declare no conflict of interest. 


\begin{abstract}
Author details
${ }^{1}$ Department of Otorhinolaryngology-Head and Neck Surgery, Hallym University Sacred Heart Hospital, Hallym University College of Medicine, Anyang, Korea. ${ }^{2}$ Department of Otorhinolaryngology-Head and Neck Surgery, Seoul National University Bundang Hospital, Seoul National University College of Medicine, Seongnam, Korea. ${ }^{3}$ Sensory Organ Research Institute, Medical Research Center, Seoul National University, Seoul, Korea. ${ }^{4}$ Institute of Allergy and Clinical Immunology, Medical Research Center, Seoul National University, Seoul, Korea. ${ }^{5}$ Department of Otorhinolaryngology-Head and Neck Surgery, Seoul National University Hospital, Seoul National University College of Medicine, 101 Daehagro, Jongro-gu, Seoul 03080, Korea.
\end{abstract}

Received: 4 August 2020 Accepted: 8 February 2021

Published online: 27 February 2021

\section{References}

1. Holick MF. Vitamin D deficiency. N Engl J Med. 2007;357(3):266-81.

2. Nair R, Maseeh A. Vitamin D: The "sunshine" vitamin. J Pharmacol Pharmacother. 2012;3(2):118-26. https://doi.org/10.4103/0976500X.95506.

3. Park JH, Hong IY, Chung JW, Choi HS. Vitamin D status in South Korean population: Seven-year trend from the KNHANES. Medicine. 2018;97(26):e11032

4. Holick MF. Vitamin D status: measurement, interpretation, and clinical application. Ann Epidemiol. 2009;19(2):73-8.

5. Holick MF, Binkley NC, Bischoff-Ferrari HA, Gordon CM, Hanley DA, Heaney RP, et al. Evaluation, treatment, and prevention of vitamin $D$ deficiency: an Endocrine Society clinical practice guideline. J Clin Endocrinol Metab. 2011;96(7):1911-30.

6. Hilger J, Friedel A, Herr R, Rausch T, Roos F, Wahl DA, et al. A systematic review of vitamin D status in populations worldwide. Br J Nutr. 2014;111(1):23-45.

7. Holick MF. Sunlight and vitamin D for bone health and prevention of autoimmune diseases, cancers, and cardiovascular disease. Am J Clin Nutr. 2004;80(6 Suppl):1678S-S1688.

8. Litonjua AA, Weiss ST. Is vitamin D deficiency to blame for the asthma epidemic? J Allergy Clin Immunol. 2007;120(5):1031-5.

9. Jung J-W, Kim J-Y, Cho S-H, Choi B-W, Min K-U, Kang H-R. Allergic rhinitis and serum 25-hydroxyvitamin D level in Korean adults. Ann Allergy Asthma Immunol. 2013;111(5):352-7.

10. Wjst M, Hypponen E. Vitamin D serum levels and allergic rhinitis. Allergy. 2007;62(9):1085-6. https://doi.org/10.1111/j.1398-9995.2007.01437.x.

11. Kim YH, Kim KW, Kim MJ, Sol IS, Yoon SH, Ahn HS, et al. Vitamin D levels in allergic rhinitis: a systematic review and meta-analysis. Pediatr Allergy Immunol. 2016;27(6):580-90.

12. Keet CA, Shreffler WG, Peng RD, Matsui W, Matsui EC. Associations between serum folate and vitamin $D$ levels and incident mouse sensitization in adults. J Allergy Clin Immunol. 2014;133(2):399-404.

13. Cheng HM, Kim S, Park G-H, Chang SE, Bang S, Won CH, et al. Low vitamin $\mathrm{D}$ levels are associated with atopic dermatitis, but not allergic rhinitis, asthma, or IgE sensitization, in the adult Korean population. J Allergy Clin Immunol. 2014;133(4):1048-55.

14. Sharief S, Jariwala S, Kumar J, Muntner P, Melamed ML. Vitamin D levels and food and environmental allergies in the United States: results from the National Health and Nutrition Examination Survey 2005-2006. J Allergy Clin Immunol. 2011;127(5):1195-202.

15. Yoo S, Lee KH, Lee HJ, Ha K, Lim C, Chin HJ, et al. Seoul National University Bundang Hospital's Electronic System for Total Care. Healthcare Inform Res. 2012;18(2):145-52.

16. WHO Study Group. Assessment of fracture risk and its application to screening for postmenopausal osteoporosis. Report of a WHO
Study Group. World Health Organization Technical Report Series. 1994;843:1-129.

17. Rim JH, Park BG, Kim JH, Kim HS. Comparison and clinical utility evaluation of four multiple allergen simultaneous tests including two newly introduced fully automated analyzers. Pract Lab Med. 2016;4:50-61.

18. Arbes SJ Jr, Gergen PJ, Vaughn B, Zeldin DC. Asthma cases attributable to atopy: results from the Third National Health and Nutrition Examination Survey. J Allergy Clin Immunol. 2007;120(5):1139-45.

19. Aryan Z, Rezaei N, Camargo CA Jr. Vitamin D status, aeroallergen sensitization, and allergic rhinitis: a systematic review and meta-analysis. Int Rev Immunol. 2017;36(1):41-53.

20. Vimaleswaran KS, Cavadino A, Hyppönen E. Evidence for a genetic interaction in allergy-related responsiveness to vitamin D deficiency. Allergy. 2012;67(8):1033-40.

21. Sadeghi K, Wessner B, Laggner U, Ploder M, Tamandl D, Friedl J, et al. Vitamin D3 down-regulates monocyte TLR expression and triggers hyporesponsiveness to pathogen-associated molecular patterns. Eur J Immunol. 2006;36(2):361-70.

22. O'Donnell AR, Toelle BG, Marks GB, Hayden CM, Laing IA, Peat JK, et al. Age-specific relationship between CD14 and atopy in a cohort assessed from age 8 to 25 years. Am J Respir Crit Care Med. 2004;169(5):615-22.

23. Munthe-Kaas MC, Torjussen TM, Gervin K, Carlsen KCL, Carlsen KH, Granum B, et al. CD14 polymorphisms and serum CD14 levels through childhood: a role for gene methylation? J Allergy Clin Immunol. 2010;125(6):1361-8.

24. Bunyavanich S, Rifas-Shiman SL, Platts-Mills TA, Workman L, Sordillo JE, Camargo CA Jr, et al. Prenatal, perinatal, and childhood vitamin D exposure and their association with childhood allergic rhinitis and allergic sensitization. J Allergy Clin Immunol. 2016;137(4):1063-70.e2.

25. Hyppönen E, Sovio U, Wjst M, Patel S, Pekkanen J, Hartikainen AL, et al. Infant vitamin d supplementation and allergic conditions in adulthood: northern Finland birth cohort 1966. Ann NY Acad Sci. 2004;1037(1):84-95.

26. Weisse K, Winkler S, Hirche F, Herberth G, Hinz D, Bauer M, et al. Maternal and newborn vitamin D status and its impact on food allergy development in the German LINA cohort study. Allergy. 2013;68(2):220-8.

27. Bettencourt A, Boleixa D, Reis J, Oliveira JC, Mendonca D, Costa PP, et al. Serum 25-hydroxyvitamin D levels in a healthy population from the North of Portugal. J Steroid Biochem Mol Biol. 2018;175:97-101.

28. Ross AC, Manson JE, Abrams SA, Aloia JF, Brannon PM, Clinton SK, et al. The 2011 report on dietary reference intakes for calcium and vitamin D from the Institute of Medicine: what clinicians need to know. J Clin Endocrinol Metab. 2011;96(1):53-8.

\section{Publisher's Note}

Springer Nature remains neutral with regard to jurisdictional claims in published maps and institutional affiliations.

Ready to submit your research? Choose BMC and benefit from:

- fast, convenient online submission

- thorough peer review by experienced researchers in your field

- rapid publication on acceptance

- support for research data, including large and complex data types

- gold Open Access which fosters wider collaboration and increased citations

- maximum visibility for your research: over $100 \mathrm{M}$ website views per year

At BMC, research is always in progress.

Learn more biomedcentral.com/submissions 